\title{
Narrating Selves from the Bible to Social Media:
}

\section{Introduction to the Forum}

Matti Hyvärinen, Tampere University

Mari Hatavara, Tampere University

Jarmila Mildorf, University of Paderborn

Philosophers as varied as Kierkegaard, Habermas, Rawls, Rorty, Nietzsche, Lukács, Bakhtin, and Benjamin have reflected on what it means to tell one's life (see Thomä 1998 for an overview). The nexus between narrating and self raises questions regarding responsibility, autonomy, and self-realization, and has also been discussed in connection with notions of virtue, the good life, self-love, and, more generally, what it means to be a human being. The philosopher Alasdair MacIntyre made a crucial contribution (1984) to thematizing the problems of narrating selves and identities.

MacIntyre's argument about everyday selves and identities builds on literary examples and concepts, making "character" a central building block of his theory (and his discussion strongly resonates with the problem of the ship of Theseus, dealt with in Mikko Keskinen's contribution to this forum). MacIntyre comments on "the contrast between criteria of strict identity, which is an all-or-nothing matter . . and the psychological continuities which are a matter of more or less. (Am I the same at fifty as I was at forty in respect of memory, intellectual powers, critical responses? More or less)" (216-17). 
People change inevitably. Conversion or loss of God's grace change the actors in the Bible (Greger Andersson’s article); autobiographer Paul Auster reflects on the difficulties he has in remembering the young boy and the young man he used to be (Jarmila Mildorf's article); and if the ship of Theseus has been entirely reconstructed, over the years, timber by timber, is it still the same ship with its identity preserved, even if its material constitution has changed? With humans, change is possibly not as dramatic, yet the difference between sameness in the form of “all-or-nothing” and sameness in the sense of “more or less” remains. MacIntyre argues that, in terms of psychological theories, there is no way of explaining or understanding personal continuity after we take into account the changes that have occurred. He proudly claims: “There is no way of founding my identity — or lack of it — on the psychological continuity or discontinuity of the self. The self inhabits a character whose unity is given as the unity of a character” (217).

The reader may be alerted by the repetitive use of the word "character" in the discussion of the source of continuity. Here, it is best understood as a conscious reference to the double meaning of the word as "characteristic features" (1) and as a “character of fiction” (2) — indeed, MacIntyre refers to Shakespeare and his plays as well as to The Count of Monte Christo. MacIntyre’s keen interest in the unity and coherence of human life encouraged his followers to understand narrative identity in terms of a complete Bildungsroman (Schechtman 96; Hyvärinen et al.). However, a much more radical idea can be found in MacIntyre's own discussion — his point about the central role of the literary as the source field of "character” (2). When reading MacIntyre this way, “character” becomes not just a researcher’s tool for understanding selves and identities, but also a resource for identity construction. Character as a resource is something that everyday readers have adopted from the 
books they have read, and then — in the spirit of Paul Ricoeur's (70-71) mimesis (3) - adapted as a perspective for their own lives. At the same time, conceiving of the person whose life one tells as a "character" also allows the narrator to design the narrative according to internal, aesthetic criteria and to absolve him- or herself from the contingencies of the life actually lived (Thomä 36). This understanding of the character not only emphasizes the interplay between literary and everyday narratives in understanding selves but also foregrounds the relevance of media and historicity in shaping these selves. The journey from the Bible to the new media is long, yet worth taking.

The contributions in this issue demonstrate the changes as well as continuities in the means, modes, and media of narrating selves. Mikko Keskinen, for example, discusses the long-obvious status of books as vehicles of communication and social exchange. At the same time, Maria Mäkelä demonstrates how new media platforms such as Facebook use the traditional literary forms for representing mind and consciousness. Both Keskinen and Mäkelä make evident the travels of cultural traditions and literary conventions all the way (at least) from the first epistolary novels to today's experimental literature and social media updates. Jarkko Toikkanen, for his part, shows how a poem from the year 1800 still sets in motion the reader's intermedial imagination to make sense of life and the world.

In his nuanced analyses of the selves in Biblical narratives, Andersson points to a variety of narrative strategies in different parts of the Bible. Some sections are shown to be more pronouncedly oriented towards historical narrative, while others use autobiography as an argument or even resort to fiction — or at least exhibit literary interest by emphasizing tellability. This diversity in presenting selves raises further questions about the historicity of narrative strategies and their relationships. 
For us living in (late) modern times, the institutions of history, fiction, non-fiction, religion, and literature are well established and discrete domains, at a clear distance from each other, though with borders sometimes transgressed. Andersson demonstrates how the narrators of Biblical times showcased diverse ways of narrating selves. Literary and everyday ways of telling may or may not have been closer to each other at the time, but the problem of how to understand the telling and its resources continues to trouble us. This raises the question of when "signposts of fictionality" (Cohn 1999) may have started to matter, for example, to the extent that they forbade historians to tell about the private thoughts of historical characters without reference to documents.

MacIntyre saw no major problem in narrating the self and identity. He would not acknowledge such reservations and hesitations as Auster has in encountering the young boy that he once was. The task of telling one's story reliably is clear enough — why use such evasive forms as you-narration, as Auster does in his autobiographical text? Yet we have long since abandoned the illusion of telling one’s self “just as it is,” without craft, evasion, or resistance. This point is amply attested to by autobiography studies (see, e.g., Smith and Watson). Maria Mäkelä's article on telling in Facebook status updates continues Andersson’s analyses of variations in self-telling by showing cases — not infrequent — when the presumably factual updates incorporate literary and artistic ambiguity as well as fictionalization and resistance to transparency of interpretation. Moreover, these artistic twists live side by side with most quotidian and non-tellable accounts of the everyday. Indeed, the literary and the everyday are not worlds apart but seem to mingle and work together in surprising contexts — even in the ways of making 
sense of one’s life or reading Wordsworth’s “Slumber,” discussed in Toikkanen’s article.

The complexity of telling the self reaches its most extreme limits in Jarkko Toikkanen’s and Mikko Keskinen’s articles. The experimental novel S, by J. J Abrams and Doug Dorst historicizes the role and relevance of the book as a material item, the codex, by taking it as a platform for an entirely new story. The novel-within-the-novel The Ship of Theseus was, as it were, written and published by a "revolutionary" Czechoslovakian author, V. M. Straka, in 1949, and has remained entirely unknown. This is the closest we probably get to the notorious "Death of the Author," the effacement of the whole person from life and literary history. Possibly, it is worth noticing that the novel is supposed to have been published a year after the Communist coup in Czechoslovakia, linking the story to the histories of World War II traumas. The novel S., however, does not simply celebrate the unsayable while its story-internal readers, two young students, start to read and communicate with each other in its margins. Even though the telling of the self (of the "author," Straka) becomes almost impossible, the “readers” keep on trying to find him in the text, and increasingly incorporate the stories of their own selves into the project, finally moving from "I”-narration to "we"-narration and from reading and commenting on Straka's work to negotiating their own relationship, with its growing intimacy. Everyday readers of The Ship of Theseus become the actual writers and creators of the self.

Something similar happens with Wordsworth’s poem “Slumber”: Toikkanen shows that the reader is left teetering between media — words and images — as well as between interpretations. Therefore, the very effort of sense-making becomes highlighted, and the interpretative connections between art and the everyday are 
exposed. While Keskinen's essay deals with the quest for significance that takes place in a book's marginalia, Toikkanen traces the readings of Wordsworth in the empty space between the two stanzas. Both essays discuss the affordances and limitations of media as modalities, imaginative resources, and material entities. Maria Mäkelä’s essay further highlights the qualities of media platforms such as Facebook, with their prompts and chosen variety of functions. And Auster's autobiography includes a section with pictures, albeit not personal or family pictures, as one may expect, but pictures of sports celebrities, film stills, advertising and other cultural artefacts that mattered to Auster as a boy — thus challenging our very expectations and traditional means of remembering one’s past. All essays in this issue aim to analyze verbalized and otherwise represented selves in different historical periods and varying narrative and medial environments (see also Hatavara et al. 2016). Bringing together the study of narratives and selves from the Bible to social media is in keeping with Monika Fludernik’s 1996 redefinition of narrativity as “mediated experientiality,” discussed by several narratologists in the previous issue of Partial Answers (16.2). The current forum explores the contexts that different types of narrative environment offer for self-expression, self-constitution, and social interaction.

Several of the articles in this forum address the theme of tellability (Andersson, Mäkelä, and Mildorf). The need to tell the quotidian, banal small facts and events of life in social media sometimes seems to obliterate the whole relevance of tellability. However, in recounting the most quotidian details of life, it is familiarity with the genres of social media and with the need to be noticed that constructs tellability. Here we see, once again, a crossover from the everyday to the literary. The reflective, literary genres are not limited to tellability in the sense of 
dramatic events and violations on the level of the storyworld. Expectations growing from the discourse and ways of telling create new kinds of tellability, encouraging one sometimes to tell "boring stories” (Tammi 2006). The average Facebook status updater seems partly to draw from similar resources in recounting the ordinary.

If the narration of the self and one’s life was for MacIntyre an answer to the dilemmas of personal continuity and integrity, it has turned out to be an incessant dilemma for the contributors to this forum: the obligation to interpret remains, even though the wish to understand the complexities of the self and its representations may be on the wane.

\section{Works Cited}

Cohn, Dorrit. 1999. The Distinction of Fiction. Baltimore: Johns Hopkins University Press.

Fludernik, Monika. 1996. Towards a 'Natural' Narratology. London: Routledge. Hatavara, Mari, Matti Hyvärinen, Maria Mäkälä, and Frans Mäyrä, eds. 2016. Narrative Theory, Literature, and New Media: Narrative Minds and Virtual Worlds. London: Routledge.

Hyvärinen, Matti, Lars-Christer Hydén, Marja Saarenheimo, and Maria Tamboukou, eds. 2010. Beyond Narrative Coherence. Amsterdam: John Benjamins.

MacIntyre, Alasdair. 1984. After Virtue: A Study in Moral Theory. Second ed. Notre Dame: University of Notre Dame Press.

Ricoeur, Paul. 1984. Time and Narrative 1. Trans. Kathleen McLaughlin and David Pellauer. 3 vols. Vol. 1. Chicago: The University of Chicago Press.

Schechtman, Marya. 1996. The Constitution of Selves. Ithaca: Cornell University 
Press.

Smith, Sidonie, and Julia Watson. 2010. Reading Autobiography: A Guide for Interpreting Life Narratives. 2nd ed. Minneapolis: University of Minnesota Press.

Tammi, Pekka. 2006. “Against Narrative ('A Boring Story’).” Partial Answers 4/2: 19-40.

Thomä, Dieter. 1998. Erzähle dich selbst: Lebensgeschichte als philosophisches Problem. Frankfurt: Suhrkamp. 